\title{
Numerical Investigation the Effect of the Different Tip Vanes on the Loading of an H-VAWT
}

\author{
Li Shoutu ${ }^{1,3}$, Wang Yin ${ }^{1,3}$, Yang Congxin ${ }^{1,3}$, and Li Ye ${ }^{2, *}$ \\ ${ }^{1}$ School of Energy and Power Engineering, Lanzhou University of Technology, Lanzhou 730050, China \\ ${ }^{2}$ School of Naval Architecture, Ocean and Civil Engineering, Shanghai Jiao Tong University, Shanghai 200240, China \\ ${ }^{3}$ Key Laboratory of Fluid machinery and Systems, Lanzhou 730050, China
}

\begin{abstract}
In this paper, the effect of the three typical tip vanes on the loading of an H-VAWT is investigated by employing the three-dimensional unsteady numerical simulation method. The results show that the both transient tangential force coefficient $\left(C_{T}\right)$ and normal force coefficient $\left(C_{n}\right)$ have obvious change when the winglet and the $\mathrm{V}$ type vane is used at the blade's tip, respectively. However, in three tip vanes, the $C_{T}$ average value is the lowest and the $C_{T}$ fluctuation characteristic is the highest when the winglet is used. Although the winglet and $\mathrm{V}$ type vane contribute to change the transient $C_{T}$ and $C_{n}$, the normal force is increased too, it results in increasing fatigue loading and decreasing lifetime for H-VAWT. By comparison, the effect of the plate vane on the loading is weaker. Additionally, the winglet is advantage to improve power coefficient in the low tip speed ratio.
\end{abstract}

\section{Introduction}

The potential advantages of Vertical Axis Wind Turbine (VAWT) are continuously explored with developing of wind energy technology. A large number of studies [1][2] have shown that VAWT is suitable for developing green buildings and urban areas with complex wind conditions. However, compared with Horizontal Axis Wind Turbine (HAWT), the VAWT has low efficiency. Therefore, many of VAWT configurations and advance technologies are employed to overcome this question [3][4]. Among these approaches, the influence of finite wing on the aerodynamic characteristic of VAWT is considered mainly [5][6]. In past researches, increasing tip device is an effective method to reduce the effect of tip vortex on VAWT. According to the literatures, the classical tip devices, mainly including winglet and elliptic endplate of different configuration, are widely used in aviation because they have the potential advantage of reducing induce drag by reducing tip loss [7]. For example, Elham A and Van Tooren MJL [8] optimized the aerodynamic and structural characteristics of wing to balance between the minimum drag and minimum weight of wing. Narayan G and John B [9] studied the tip vortex structure induced by the winglet of the subsonic wings , and the results show that the winglet is more suitable for the lower aspect ratio wings.

With the development of wind turbine technology, some of researchers have turned their attention to the effects of different tip devices on the performance of wind turbines. Shimizu Y [10][11] studied the configuration of tip vane (Mie-Type Tip Vane) that was installed on blades of HAWT , and obtained the optimal configuration of tip vane. Meanwhile, the literature shows that the power output of HAWT could is improved by adding tip vane. Compared with HAWT, the tip device is rarely applied to VAWT. The literature [12] shows that the start-up performance of VAWT is improved by installing winglet at both ends of its blades, but this literature did not describes research process in detail, including the shape of winglet and experimental approach.

Additionally, numerical simulation method is considered as a potential research technique on the $\mathrm{H}$ VAWT [13]. The Shear Stress Transport (SST) $k$ $\omega$ transitional turbulence model have more accurate results compare with the other fully turbulence model because it could capture the flow separation phenomena [3][14]. Although LES and RANS-LES turbulence model are also regarded as good turbulence model, the computational efficiency is lower compared with $k-\omega$ SST model.

The tip device is widely employed on the blade of wind turbine by method of computationally and experimentally. However, the lots of literatures show that there are a little of researches to discuss the effect of tip device on the loading of VAWT compared with HAWT.

Therefore, in present study, we investigate effect of three different tip devices on the loading of VAWT by employing three-dimensional unsteady numerical simulation method.

\section{Numerical methods}

\footnotetext{
* Corresponding author: ye.li@sjtu.edu.cn
} 
In this paper, we employ the $3 \mathrm{D}$ computational domain to analyze loading of the single blade H-VAWT when three different tip vanes are installed on the blade tip, respectively. The blade of $\mathrm{H}-\mathrm{VAWT}$ is composed by NACA0012 airfoil [15], where the chord length (C) is $91.4 \mathrm{~mm}$, the blade length (L) is $910 \mathrm{~mm}$, the rotor diameter (D) is $1220 \mathrm{~mm}$.

\subsection{Description of different tip vanes}

Fig. 1 shows the sketches of the plate vane, $V$ type vane and winglet. The detailed parameters of the three types of blades are shown in Table 1. Moreover, the thickness of $\mathrm{V}$ type vane and plate vane are $1 \mathrm{~mm}$, it aims to reduce the effect of the vane itself on the contents of researches.

\subsection{Geometry and boundary conditions of fluid field}

Fig.2 shows the schemes of geometry and the boundary conditions of the numerical simulation for H-VAWT, where the $\mathrm{D}$ is the diameter of rotor. The inlet is set as velocity inlet and the distance is 10D away from the axis of the rotor, and the free stream wind velocity is $12 \mathrm{~m} / \mathrm{s}$. The outlet is set as outflow and the distance is 20D away from the axis of the rotor. The walls of airfoil are set as non-slip wall. The all of walls of the rotor that are existed between the rotor and far field are set as interface. The coordinate system is set as rotating coordinate system. The standard atmosphere characteristics are used in simulated flow field, including pressure, density and dynamic viscosity.

In present work, the first layer of grid cells has a height of $0.03 \mathrm{~mm}$ and a growth rate of 1.16 to satisfy a $\mathrm{Y}+$ value of less than 5 .

Table 1. Parameters list of tip vane

\begin{tabular}{|c|c|c|}
\hline parameter & value & unit \\
\hline R1 & 20 & $\mathrm{~mm}$ \\
\hline R2 & 15 & $\mathrm{~mm}$ \\
\hline A & 45 & $\mathrm{~mm}$ \\
\hline B & 73.1 & $\mathrm{~mm}$ \\
\hline C & 73.1 & $\mathrm{~mm}$ \\
\hline $\mathrm{D}$ & 25 & $\mathrm{~mm}$ \\
\hline $\mathrm{E}$ & 10 & $\mathrm{~mm}$ \\
\hline$\alpha$ & 20 & $\circ$ \\
\hline$\beta$ & 15 & $\circ$ \\
\hline $\mathrm{L}$ & 60 & $\mathrm{~mm}$ \\
\hline $\mathrm{R} 3$ & 70 & $\mathrm{~mm}$ \\
\hline$\theta$ & 60 & $\circ$ \\
\hline
\end{tabular}

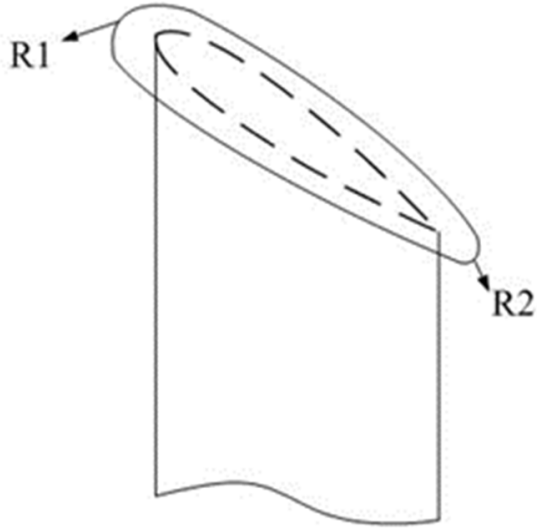

(a)Plate vane

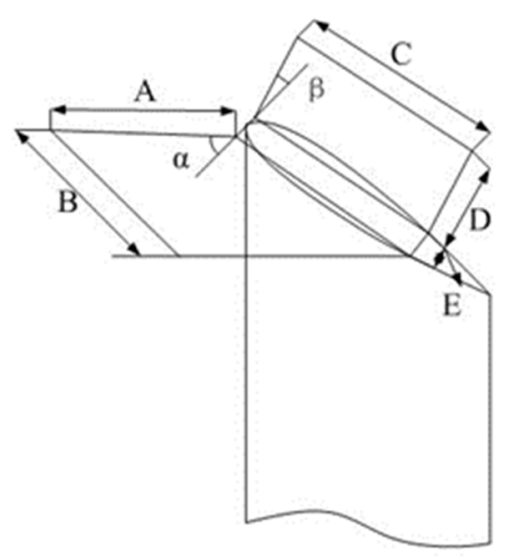

(b) V type vane

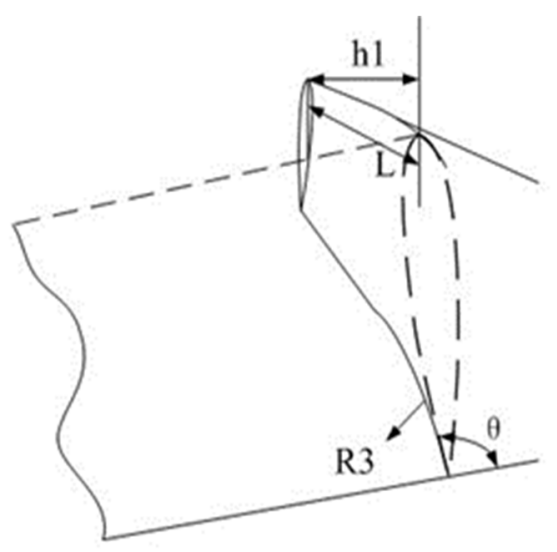

(c) Winglet

Fig.1. Sketch of three different tip vanes

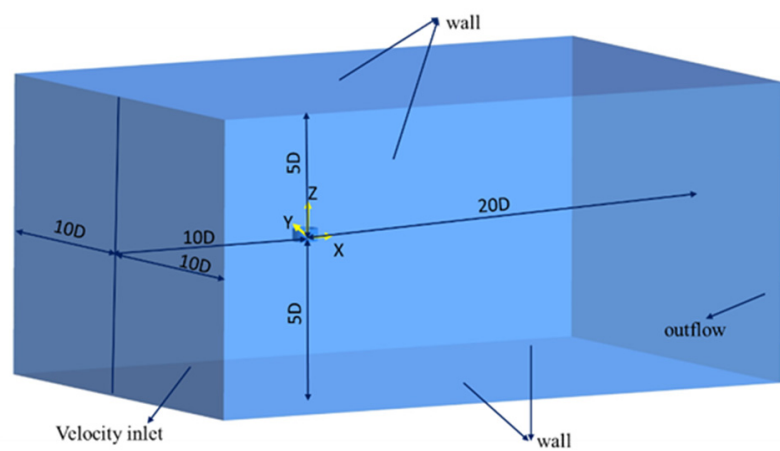

(a) Geometric description of the computational domain

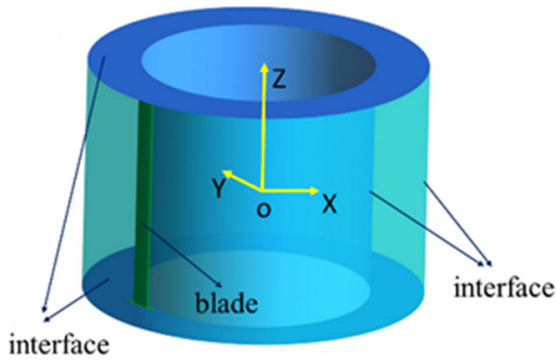

(b)Detailed description of rotor

Fig.2. Scheme of geometry and boundary conditions for H-VAWT 


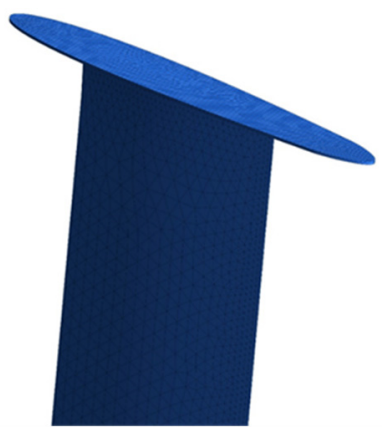

(a)Plate vane

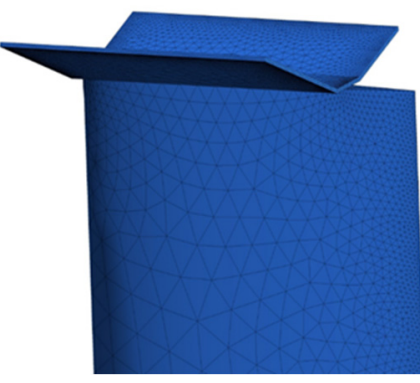

(b) V type vane

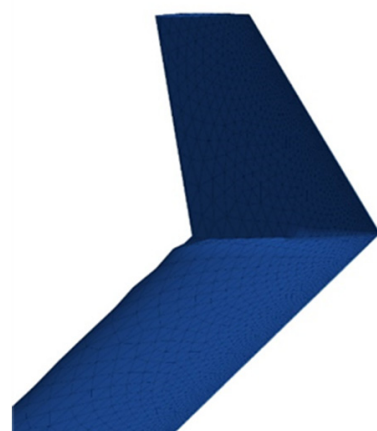

(c) Winglet

Fig.3. The detailed grids around different blades tip

\subsection{Turbulence models and simulation setup}

The SST $k$ - $\omega$ turbulence model is employed in this paper. The spatial and temporal discretization are achieved by considering second order schemes. The continuity equations and momentum equations are solved by segregated approach. The pressure-velocity coupling is achieved by considering SIMPLEC scheme. The time step $\triangle \mathrm{t}=0.5 \omega^{-1}[16]$ ( $\omega$ is rotate speed, the unit is $\left.\mathrm{rad} / \mathrm{s}\right)$ is adopted.

It is important to ensure the grid-independent in the numerical method. In this paper, the lift-drag ratio $\left(C_{L} / C_{d}\right)$ of NACA0012 airfoil is investigated when the angle of attack is $5^{\circ}$ and the investigated position located at $\mathrm{Z}=0$. Fig. 4 shows the $\mathrm{C}_{\mathrm{L}} / \mathrm{C}_{\mathrm{d}}$ at the different of cells number when the angle of attack is $5^{\circ}$. The maximum $\mathrm{C}_{\mathrm{L}} / \mathrm{C}_{\mathrm{d}}$ of NACA0012 is converged when the total number of cells is greater than $5 \times 10^{6}$ compared with the results of literature [17]. Therefore, the following numerical simulations are achieved with the number of cells between $5 \times 10^{6}$ and $5.7 \times 10^{6}$.

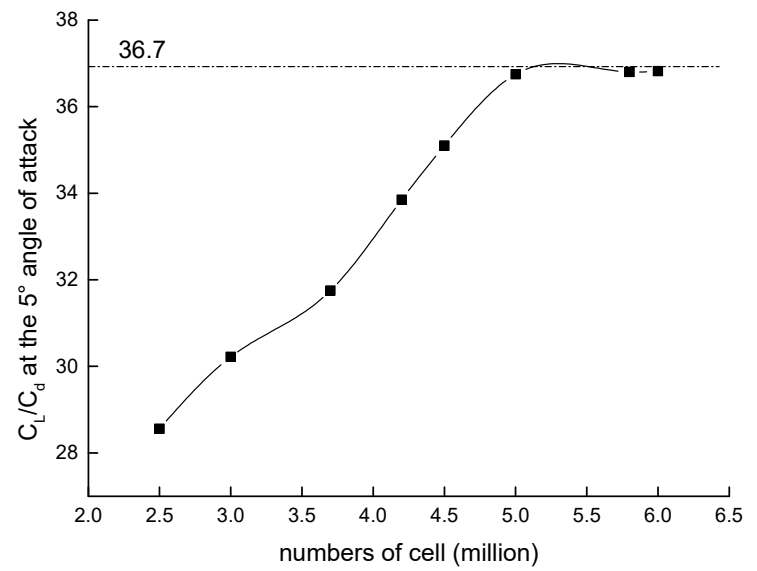

Fig.4. The $C_{L} / C_{d}$ versus the number of cells at the $5^{\circ}$ angle of attack

\section{Results and discussions}

In this section, the results of this paper are descripted and presented.

\subsection{The effect of different tip vane on loading of H-VAWT}

The aerodynamic loadings of the H-VAWT with single blade were analyzed by employing the $3 \mathrm{D}$ numerical method. The loadings performance were given by the tangential force coefficient $\left(C_{T}\right)$, normal force coefficient $\left(C_{n}\right)$ and torque coefficient $\left(C_{m}\right)$, and they are defined by Equations (1), (2) and (3) respectively.

$$
\begin{aligned}
C_{T} & =\frac{F_{t}}{0.5 \rho L C V_{\infty}^{2}} \\
C_{n} & =\frac{F_{n}}{0.5 \rho L C V_{\infty}^{2}} \\
C_{M} & =\frac{\mathrm{M}}{0.5 \rho L C^{2} V_{\infty}^{2}}
\end{aligned}
$$

Where $\rho$ presented the air density, $V_{\infty}$ was the free stream velocity, $F_{t}$ was the tangential force, $F_{n}$ was the normal force and $M$ was the torque. Which the power coefficient $(C p)$ was defined by the relating with $C_{m}$ and tip speed ratio $(\lambda)$ :

$$
C_{p}=C_{m} \cdot \lambda
$$

Fig.5 showed the comparative results of the $C_{T}$ between the without tip vane and the three different tip vanes on the blade tip of H-VAWT. The effect of the three different tip vanes on the $C_{T}$ of an H-VAWT was obvious. Moreover, the $C_{T}$ was increased in a period of rotation for the rotor, especially, in the downstream side of the rotor $\left(180^{\circ} \leq \theta \leq 360^{\circ}\right)$, where $\theta$ was the azimuthal angle. The maximum $C_{T}$ value, at the azimuthal angle $270^{\circ}$, had obviously improve when the tip vanes were used. However, in the regions from azimuthal angle of $180^{\circ}$ to $250^{\circ}$, the $C_{T}$ values of the winglet and $\mathrm{V}$ type vane were lower than $C_{T}$ values of without vane, on the contrary, the plate vane performed better than the other two tip vanes. Additionally, although the $C_{T}$ values of the $\mathrm{V}$ type vane and winglet were higher than the plate vane in the upstream side of the rotor $\left(0^{\circ} \leq \theta \leq 180^{\circ}\right)$, the $C_{T}$ was negative. While the variable trend of $C_{T}$ was adverse in the downstream side of the rotor. However, the maximum $C_{T}$ happened in the upstream side and downstream side of the rotor when the $\mathrm{V}$ type vane and winglet was installed on the blade tip, respectively. 


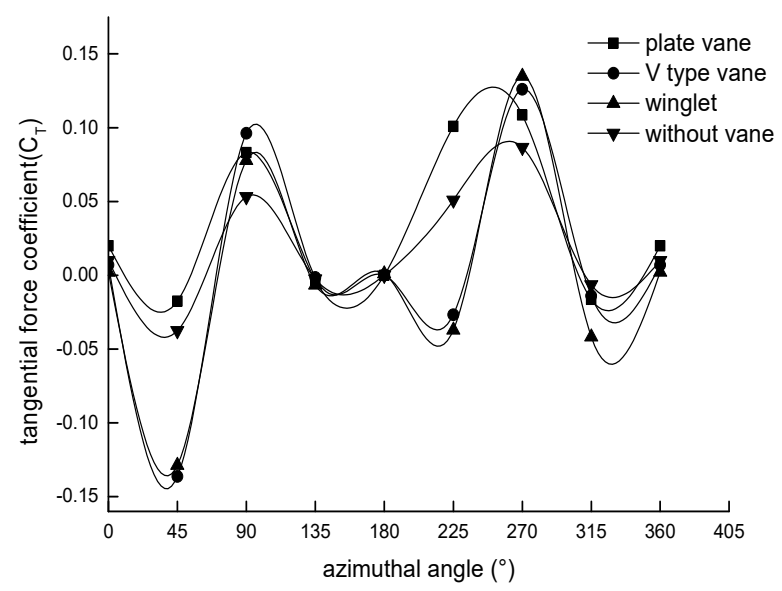

Fig.5. The tangential force coefficient at the different of azimuthal angles

Fig.6 showed the results of $C_{n}$ at the different azimuthal angles. The $C_{n}$ values of the $\mathrm{V}$ type vane and winglet had obvious advantage compared with the plate vane in upstream side of the rotor, and the positive and negative maximum $C_{n}$ were happened by employing the winglet both in the upstream side and downstream side of the rotor. Moreover, the negative maximum $C_{n}$ value was happened at the azimuthal angle $270^{\circ}$ in a period of rotation for the rotor. However, in the downstream side of the rotor, the $C_{n}$ variable trend of the $\mathrm{V}$ type vane was gentle compared with $C_{n}$ of the winglet, and the $C_{n}$ was increased with increasing of the $\theta$ from $250^{\circ}$ to $315^{\circ}$. Obviously, although the plate vane was advantage for improving $C_{n}$, especial in the upstream side of rotor, the influence was not too obvious compared with the $\mathrm{V}$ type vane and winglet.

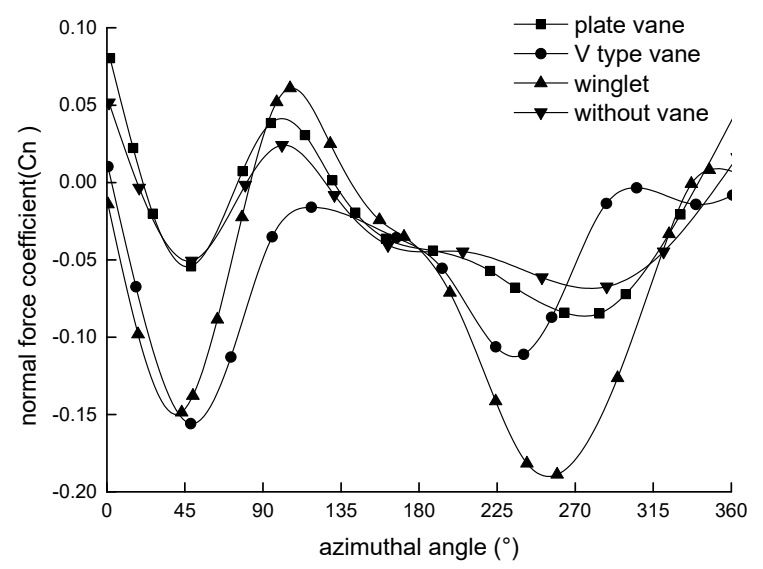

Fig.6. The normal force coefficient at the different of azimuthal angles

The results of the $C_{m}$ at the different azimuthal angles when the three different vanes are employed as shown in Fig.7. Both in upstream side and downstream side of the rotor, the $C_{m}$ value of the winglet performed better than the $\mathrm{V}$ type vane and plate vane, especially in the upstream side. Moreover, the winglet obtained the maximum $C_{m}$ value and the modest minimum $C_{m}$ value. Meanwhile, in the downstream side of the rotor, the plate vane and $\mathrm{V}$ type vane kept the almost same of trend of the $C_{m}$. However, the $C_{m}$ of the winglet had the close the $C_{m}$ values compared with the other two tip vanes when the $\theta$ values from $135^{\circ}$ to $225^{\circ}$. Additionally, the staring torque was improved by employing the winglet, while the staring torque was same when $\mathrm{V}$ type vane and plate vane were used.

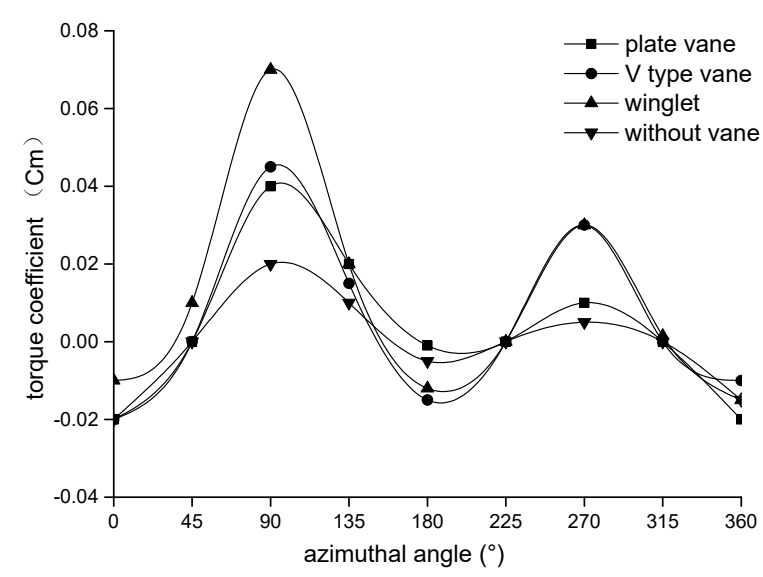

Fig.7. The torque coefficient at the different of azimuthal angle

The comprehensive aerodynamic characteristics were shown in Fig.8. Compared with the $C p$ of the without vane, the $C p$ of the winglet performed better than the $\mathrm{V}$ type vane and plate vane, especially in the lower tip speed ratio $(\lambda)$ regions. However, when the $\lambda$ values were greater than 5 , the $C p$ of the three tip vanes performed the almost same.

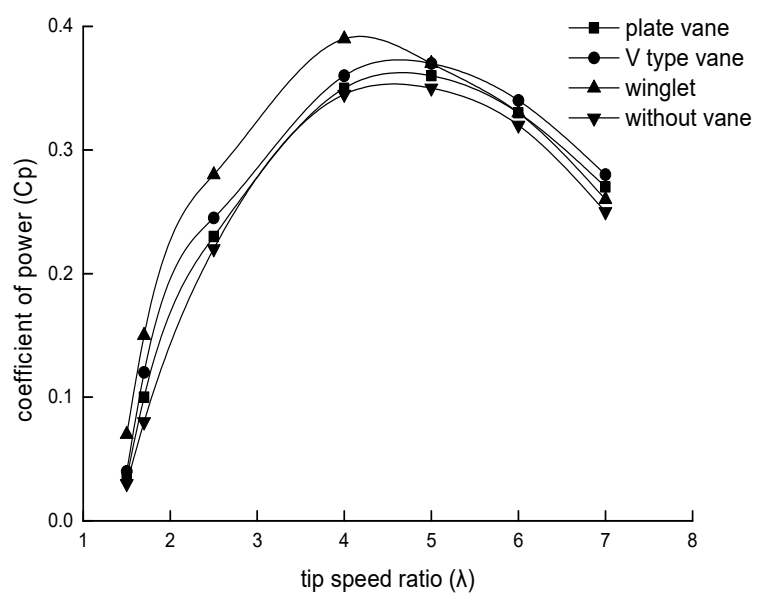

Fig.8. The power coefficient versus tip speed ratio

The table2 showed that the average values of $C_{T}, C_{m}$ and $C_{n}$ when the three different tip vanes was installed on the blade tip of H-VAWT, respectively. Moreover, the AVG. $\Delta C_{T}$ and AVG. $\Delta C_{n}$ were defined by Equation:

$$
\begin{aligned}
& \text { AVG. } \Delta C_{T}=C_{\text {T.max }}-C_{\text {T.min }} \\
& \text { AVG. } \Delta C_{n}=C_{n . \text { max }}-C_{n . \text { min }}
\end{aligned}
$$

Here, the AVG. $\Delta C_{T}$ and AVG. $\Delta C_{n}$ were employed to illuminate fluctuate of $C_{T}$ and $C_{n}$. Compared with the results of the without vane, the plate vane helped to improve the average $C_{T}$ value, however, it was disadvantaged for improving the average $C_{m}$ and $C_{n}$ values. On the contrary, in terms of improving average $C_{m}$ values, the winglet performed better. Additionally, the $\mathrm{V}$ type vane and winglet had the almost same of average $C_{n}$ values. Obviously, the values fluctuate of the 
$C_{T}$ and $C_{n}$ were increased after adding the tip vane, especially was the winglet vane, the AVG. $\Delta C_{T}$ and AVG. $\Delta C_{n}$ was increased $116 \%$ and $108 \%$, respectively. While the AVG. $\Delta C_{T}$ and AVG. $\Delta C_{n}$ of the $\mathrm{V}$ type vane was increased $116 \%$ and $41.6 \%$, the plate vane was increased $8.3 \%$ and $41.6 \%$.

Table.2. The average values of $C_{T}, C_{m}$ and $C_{n}$ when the different tip vanes were used

\begin{tabular}{|c|c|c|c|c|c|}
\hline \multirow{2}{*}{ Force } & \multicolumn{2}{|c|}{$\begin{array}{c}\text { Tangential force } \\
\text { coefficient }\end{array}$} & \multicolumn{2}{c|}{$\begin{array}{c}\text { Normal force } \\
\text { coefficient }\end{array}$} & $\begin{array}{c}\text { Torque } \\
\text { coeffici } \\
\text { ent }\end{array}$ \\
\cline { 2 - 6 } & Average & AVG. $\Delta C_{T}$ & $\begin{array}{c}\text { Averag } \\
\mathrm{e}\end{array}$ & $\begin{array}{c}\text { AVG. } \\
\Delta C_{n}\end{array}$ & $\begin{array}{c}\text { Averag } \\
\mathrm{e}\end{array}$ \\
\hline Plate vane & 0.033 & 0.13 & -0.017 & 0.17 & 0.003 \\
\hline $\begin{array}{c}\text { V type vane } \\
\text { Winglet } \\
\text { vane }\end{array}$ & 0.006 & 0.26 & -0.05 & 0.17 & 0.005 \\
\hline $\begin{array}{c}\text { Without } \\
\text { vane }\end{array}$ & 0.0004 & 0.26 & -0.06 & 0.25 & 0.01 \\
\hline
\end{tabular}

\section{Conclusions}

In this paper, we investigate the effect of the three classic tip vanes on loading of the single blade H-VAWT by employing $3 \mathrm{D}$ unsteady numerical method.

The transient $C_{T}$ value has obviously changed when the winglet and V type vane is used at the blade's tip, respectively. However, the $C_{T}$ average value is the lowest and the fluctuation characteristic is the highest when the winglet is used. On the contrary, although the transient $C_{T}$ is lowest when the plate vane is employed, $C_{T}$ average value is the highest, while the fluctuation characteristic is the lowest.

In terms of $C_{n}$, the effect of the winglet and $\mathrm{V}$ type vane on transient $C_{n}$ are also obvious, moreover, the average $C_{n}$ value and the fluctuation characteristic are highest when winglet is used. Meanwhile, the $\mathrm{V}$ type vane and plate present same of the fluctuation characteristic.

Although the winglet and $\mathrm{V}$ type vane help to change the transient $C_{T}$ and $C_{n}$, the tangential and normal force are increased too, it results in increasing fatigue loading and decreasing lifetime for H-VAWT. However, the plate vane is weaker on the effecting loading.

The winglet performs better in terms of improve $C_{m}$, moreover, it improves power coefficient in the low tip speed ratio area.

\section{References}

1. G. Bedon, S. De Betta, E. Benini, Renew Energy 94, 328-40 (2016)

2. F. Toja-Silva, A. Colmenar-Santos, M. Castro-Gil, Renew Sustain Energy Rev 24, 364-78 (2013)

3. M. Ghasemian, Z.N. Ashrafi, A. Sedaghat, Energy Convers Manag 149, 87-100 (2017)

4. A. Bianchini, F. Balduzzi, J.M. Rainbird, J. Peiró, J.M.R. Graham, G. Ferrara, et al, Energy Convers Manag 106, 373-84 (2015)
5. K.H. Wong, W.T. Chong, N.L. Sukiman, S.C. Poh, Y.C. Shiah, C.T. Wang, Renew Sustain Energy Rev 73,904-21 (2017)

6. S. Zanforlin, S. Deluca, Energy 148, 179-95 (2018)

7. L.B. Gratzer, Patent - Split Blended Winglet (2014)

8. A. Elham, M.J.L. Van Tooren, Aerosp Sci Technol 37, 93-109 (2014)

9. G. Narayan, B. John, Aerosp Sci Technol 58, 32840 (2016)

10. Y. Shimizu, T. Yoshikawa, S. Matsumura, J Fluids Eng 114, 293-7 (1994)

11. Y. Shimizu, H. Imamura, S. Matsumura, T. Maeda, J Sol Energy Eng 117, 297-303 (1995)

12. N.A. Ahmed, K.J. Netto, Applied Mechanics and Materials Vol.607, 581-7 (2014)

13. P. Fuglsang, C. Bak, Wind Energy 7, 145-62 (2004)

14. M. Raciti Castelli, A. Englaro, E. Benini, Energy 36, 4919-34 (2011)

15. B.T. Webster, An experimental study of an airfoil undergoing cycloidal motion. Texas Tech University (1978).

16. K. McLaren, A numerical and experimental study of unsteady loading of high solidity vertical axis wind turbines, McMaster (2011)

17. http://airfoiltools.com/ n.d 